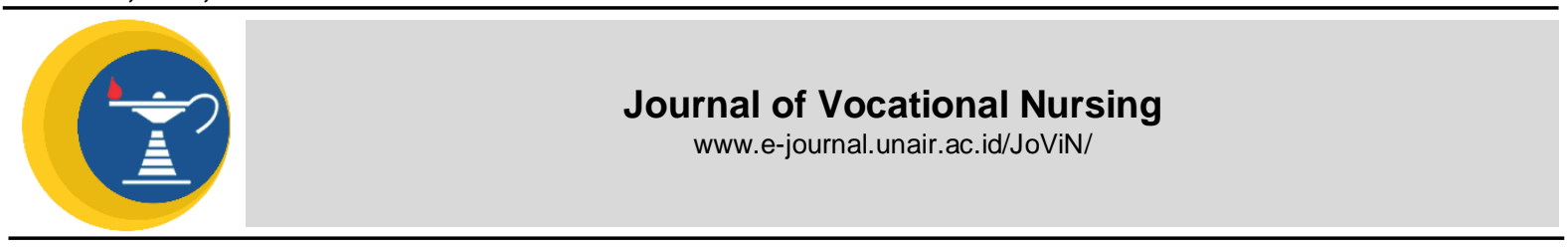

\title{
RELATIONSHIP PARENTING AND MENTORING ONLINE LEARNING FOR SCHOOL AGE DURING THE COVID-19 PANDEMIC IN TANGERANG WEST JAVA
}

\author{
Nabila Aisyah Safira, Jaeudin
}

Research Report

SRIKES YATSI Tangerang

\begin{abstract}
A B STRACT
Introduction: The parenting pattern of parents will affect online learning assistance for children. The better the parenting pattern, the better in providing assistance. At this time parental assistance is urgently needed to assist children in online learning. Objectives: Purpose: This study was conducted to determine the relationship between parenting styles and child learning assistance during the COVID-19 pandemic in Sepatan village, Rt 01/05, Sepatan sub-district. Methods: The type of research used in this study is a quantitative research design using a descriptive correlation research design using a cross sectional approach. By taking a sample using the Solvin formula as many as 109 respondents using a perposive sampling technique on parents who have elementary school age children, The statistical test used in this research is the chi-square test. Results: From the results of the bivariate analysis using the chi square test, the results obtained a significance value (2sided) or " $p$ value" 0.000 where if the significance value or " $p$ value" $<0.05$ then $\mathrm{Ha}$ is accepted and $\mathrm{HO}$ is rejected, which means "There is a relationship between parenting patterns and online learning assistance for children during the covid-19 pandemic in the village of Sepatan Tengah, Rt 01/Rw 01, Sepatan sub-district". Conclusion: Based on the analysis, it was found that there is a strong relationship between parenting applied and online learning assistance for children during the Covid-19 pandemic.
\end{abstract}

ARTICLE INFO

Received October 16, 2021

Accepted October 30, 2021

Online October 31, 2021

*Correspondence:

Nabila Aisyah Safira

*Email:

nabilaaisyah1028@gmail.com

Keywords:

Mentoring, Online Learning,

Parenting

\section{INTRODUCTION}

Currently the world is experiencing a COVID-19 pandemic caused by Corona Virus Disease (Covid-19), including in Indonesia as a result of this pandemic, the Government has made many changes including controlling economic activities, Health, Education, this is done to prevent transmission covid-19 in society. According to data on the distribution of COVID-19 cases worldwide, as of March 25, 2021, there were $125,327,779$ confirmed cases, 101,171,020 recovered cases and $2,755,275$ deaths. Then data on Covid-19 cases in Indonesia, based on information dated 25-03-2021. Cases in Indonesia reached $1,476,452$ positive, $1,312,543 \quad(86.8 \%)$ recovered, $39,983(2.7 \%)$ died and 145,628 active cases $(10.5 \%)$ from confirmed data, There are 25 sub-districts affected by COVID19 including Sepatan (194 confirmed cases), (175 cases recovered), ( 1 case died). The world is experiencing a pandemic, so there is a change from face-to-face learning to online learning in accordance with "Official Circular Letter of the Minister of Education and Culture Number 36962/MPK.A/HK/2020 concerning online learning and working from home, to prevent the spread of the corona virus". Learning activities are carried out online at home, now parents need to provide intense guidance to children so that children understand learning with new methods. A simple example is the teacher giving assignments via E-mail, WhatsApp groups, Google Classroom, Google Meet, Quizizz and Zoom in online learning. (1 case died). (covid19.tangerangkab.go.id accessed on March 25, 2021).

The world is experiencing a pandemic, so there is a change from face-to-face learning to online learning in accordance with "Official Circular Letter of the Minister of Education and Culture Number 36962/MPK.A/HK/2020 concerning online learning and working from home, to prevent the spread of the corona virus". Learning activities are carried out online 
at home, now parents need to provide intense guidance to children so that children understand learning with new methods. A simple example is the teacher giving assignments via E-mail, WhatsApp groups, Google Classroom, Google Meet, Quizizz and Zoom in online learning. The world is experiencing a pandemic, so there is a change from face-to-face learning to online learning in accordance with "Official Circular Letter of the Minister of Education and Culture Number 36962/MPK.A/HK/2020 concerning online learning and working from home, to prevent the spread of the corona virus". Learning activities are carried out online at home, now parents need to provide intense guidance to children so that children understand learning with new methods. A simple example is the teacher giving assignments via E-mail, WhatsApp groups, Google Classroom, Google Meet, Quizizz and Zoom in online learning. Because the world is experiencing a pandemic, so there is a change from face-to-face learning to online learning in accordance with "Official Circular Letter of the Minister of Education and Culture Number 36962/MPK.A/HK/2020 concerning online learning and working from home, to prevent the spread of the corona virus".

Learning activities are carried out online at home, now parents need to provide intense guidance to children so that children understand learning with new methods. A simple example is the teacher giving assignments via E-mail, WhatsApp groups, Google Classroom, Google Meet, Quizizz and Zoom in online learning. Because the world is experiencing a pandemic, so there is a change from face-to-face learning to online learning in accordance with "Official Circular Letter of the Minister of Education and Culture Number 36962/MPK.A/HK/2020 concerning online learning and working from home, to prevent the spread of the corona virus". Learning activities are carried out online at home, now parents need to provide intense guidance to children so that children understand learning with new methods. A simple example is the teacher giving assignments via E-mail, WhatsApp groups, Google Classroom, Google Meet, Quizizz and Zoom in online learning. Learning activities are carried out online at home, now parents need to provide intense guidance to children so that children understand learning with new methods. A simple example is the teacher giving assignments via E-mail, WhatsApp groups, Google Classroom, Google Meet, Quizizz and Zoom in online learning. Learning activities are carried out online at home, now parents need to provide intense guidance to children so that children understand learning with new methods. A simple example is the teacher giving assignments via E-mail, WhatsApp groups, Google Classroom, Google Meet, Quizizz and Zoom in online learning. (Iftitah \& Anawaty, 2020) Parents are the first environment that children see so that they can imitate, and their character is formed through parental guidance (Nurpratiwiningsih et al., 2021). Every parent has a different parenting pattern, so the care given to children will cause different behavior too(Hasanah, nd). Parenting patterns vary greatly depending on how the family in educating children at home. The types of parenting include (1) authoritarian parenting (2) permissive parenting (3) democratic parenting(Sari \& Suprapti, 2018) In the online period, parental assistance is also very necessary which can be interpreted as mentoring is a coaching to shape the child's character (Riati, 2016). Learning mentoring is where parents foster and accompany children in carrying out learning activities in order to form good character and behavior for children(Sari \& Suprapti, 2018).

\section{MATERIALS AND METHODS}

The research design used in this study is a quantitative type of research using a descriptive correlation research design. In this study, a cross sectional approach is used, which is a process in which the data is the independent variable (free) parenting patterns and the dependent variable (bound) online learning assistance for children. school age during the COVID-19 pandemic (Sugiyono, 2016). The location to be researched is in the village of Sepatan Tengan Rt 001/001, Sepatan sub-district, Tangerang district, Banten province. In this study, the sampling technique used perposive sampling, namely data collection by determining the sample (Sugiyono, 2016). With a total of 109 respondents, parents who have school-age children, and parents who are willing to become respondents, The instrument used in this study was a questionnaire/questionnaire on parenting patterns and learning assistance. the researcher conducted validity, reliability and normality tests to determine whether the questionnaire used was valid or not, to know the data was reliable and the results were normal. In conducting data processing, researchers used univariate and bivariate tests, namely the chi-square test. 
Univariate Analysis

\section{RESULTS}

Table 1. of Frequency Distributions Based on Independent Variables Parenting Patterns in In Tangerang West Java

\begin{tabular}{ccc}
\hline Independent Variable & Frequency & Percentage (\%) \\
\hline Good & 28 & $25.7 \%$ \\
Good enough & 43 & $39.4 \%$ \\
Bad & 38 & $34.9 \%$ \\
\hline Total & 109 & $100 \%$ \\
\hline
\end{tabular}

Based on the analysis in table 5.6 that in general the parenting style that is widely applied is the fairly good category, totaling 43 people (39.4\%) out of 109 respondents.

Table 2. Frequency Distribution Table Based on the Dependent Variable Online Learning Assistance for Children During the Covid-19 Pandemic in Tangerang West Java

\begin{tabular}{ccc}
\hline Independent Variable & Frequency & Percentage (\%) \\
\hline Good & 29 & $26.6 \%$ \\
Good enough & 42 & $38.5 \%$ \\
Bad & 38 & $34.9 \%$ \\
\hline Total & 109 & $100 \%$ \\
\hline
\end{tabular}

Based on the analysis from table 5.7 that in general, online learning assistance for children is widely applied, namely in the fairly good category, totaling 42 people (38.5\%) of 109 respondents.

Table 3. Chi Square Analysis Table of Parenting Patterns with Online Learning Assistance for Children During the Covid-19 Pandemic in Tangerang West Java

\begin{tabular}{ccccccc}
\hline $\begin{array}{c}\text { Parenting } \\
\text { Parenting }\end{array}$ & \multicolumn{3}{c}{$\begin{array}{c}\text { Online Learning Assistance for } \\
\text { Children During the Covid-19 } \\
\text { Pandemic }\end{array}$} & Total & $\begin{array}{c}\text { Asymptotic } \\
\text { Significance (2-sided) } \\
\text { or P Value }\end{array}$ \\
\cline { 2 - 6 } & Good & enough & Bad & N & $\%$ & \multirow{2}{*}{0.000} \\
Enell & 22 & 6 & 0 & 28 & $25.7 \%$ & \\
Bad & 7 & 36 & 0 & 43 & $39.4 \%$ & \\
\hline Total & 0 & 0 & 38 & 38 & $34.9 \%$ & \\
\hline & 29 & 42 & 38 & 109 & $100 \%$ & \\
\hline
\end{tabular}

Based on the analysis of table 5.8 , the results of the chi square test obtained asymptotic significance (2-sided) or " $p$ value" 0.000 where if the significance value or "p value" $<0.05$ then Ha is accepted and $\mathrm{HO}$ is rejected, which means "There is a relationship between parenting parents with online learning assistance for children during the COVID-19 pandemic"

Table 4. Table of Correlation Test Analysis of Parenting Patterns with Online Learning Assistance for Children During the Covid-19 Pandemic in Tangerang West Java

\begin{tabular}{cccc}
\hline & Parenting style & & $\begin{array}{c}\text { Online learning } \\
\text { assistance for children }\end{array}$ \\
\hline Parenting style & Pearson Correlation & 1 & $.822^{\star *}$ \\
& Sig. (2-tailed) & & .000 \\
& $N$ & 109 & 109 \\
\hline Online & Pearson Correlation & $.822^{\star *}$ & 1 \\
learning & Sig. (2-tailed) & .000 & 109 \\
assistance for & $\mathrm{N}$ & 109 & 109 \\
children & & & \\
\hline
\end{tabular}

Based on the results of the correlation test above, it proves that there is a "very strong relationship" between parenting and online learning assistance for children during the COVID-19 pandemic, it can be seen from the Significance and Pearson Correlation scores. If the significance value is $<0.05$, then it is correlated if the significance value is $>0.05$. Not correlated. Meanwhile, if the Pearson
Correlation value is $0.81-1.00$, it is said to have a very strong or perfect correlation.

From the data above, we can see that the value of Sig. (2-tailed) 0.000 means $<0.05$ there is a relationship between the two variables, while the Pearson Correlation value of parenting and online learning assistance for children is 0.822 which means that there is a very strong or perfect correlation between "The relationship between parenting patterns and 
online learning assistance. in children during the COVID-19 pandemic.

\section{DISCUSSION}

Based on the bivariate analysis test from table 5.8, the conclusion is that from the results of the chi square test, the Asymptotic Significance value (2-sided) or "p value" is 0.000 where if the significance value or $\mathrm{p}$ value" $<0.05$ then $\mathrm{Ha}$ is accepted and $\mathrm{HO}$ is rejected. meaning "There is a relationship between parenting patterns and online learning assistance for school-age children during the covid-19 pandemic in the village of Sepatan Tengah Rt 01/Rw 01, Sepatan sub-district".

Then in addition to the chi square test, the researchers conducted a correlation test to determine the strength between the two variables. 19, Can be seen from the value of Significance and Pearson Correlation. If the significance value is $<0.05$ then it is correlated, if the significance value is $>0.05$ it is not correlated. Meanwhile, if the Pearson Correlation value is $0.81-1.00$, it is said to have a very strong or perfect correlation.

From these results, we can see that many parents apply democratic parenting to their children in the village of Sepatan, so that in the current pandemic situation, parenting is closely related to the learning assistance provided to children when children are undergoing the online learning process to support their abilities and abilities. children's activeness in learning. And find out how far the child's development in learning during the covid-19 pandemic is carried out at home

This research is in line with the results of research(Anggraeni et al., 2020) entitled "The trend of parenting parents in the blended learning model during the covid-19 pandemic" with the results of research that parenting applied according to the context and needs of children will cause positive things for children so that children will be enthusiastic in learning.

In addition, this research is also supported by the journal(Nurjanah \& Irma, 2020) with the title "The Role of Parents in AUD Online Learning Assistance During the Covid19 Pandemic" with the conclusion that the role of parents in nurturing and assisting children in learning is needed so that children can focus on online learning, Parents really help children in doing assignments -tasks given by the teacher through online learning, and helping children explain lessons that have not been understood, helping children when experiencing problems in online learning.

\section{CONCLUSION}

Based on the results of the discussion of the research on the relationship between parenting patterns and online learning assistance for children during the Covid-19 pandemic in the village of Sepatan Tengah Rt 01/ Rw 01, Sepatan District, the following conclusions were found, there is a "very strong relationship between parenting patterns and learning assistance online for school-age children during the COVID-19 pandemic" the dominant parenting pattern carried out by parents is democratic parenting.

Hopefully parents can apply good parenting patterns for children so that they can establish good and harmonious communication, so that parents and children can accompany each other so that parents can know the developments that are in their children, so that children feel cared for and loved and loved by others. both parents. With this research, residents in Sepatang Tengah Rt 01/ Rw 01 can improve parenting and online learning assistance for children, so that parents can know the process of child development, Help children learn online while at home, and shape children's character to become good people. , Establish good communication with children so that children feel cared for, loved and cared.

\section{REFERENCES}

Anggraeni, CS, Hidayati, N., Farisia, H., \& Khoirulliati, K. (2020). Trends in Parenting Patterns in Assisting Blended Learning Models during the Covid-19 Pandemic. JECED: Journal of Early Childhood Education and Development, 2(2), 97108. https://doi.org/10.15642/jeced.v2i2.915

Hasanah, U. (nd). Parenting patterns in shaping children's character. 72-82.

Iftitah, SL, \& Anawaty, MF (2020). The Role of Parents in Accompanying Children at Home During the Covid-19 Pandemic JCE (Journal of Childhood Education), 4(2), 71. https://doi.org/10.30736/jce.v4i2.256

Nurjanah, YS, \& Irma, CN (2020). The Role of Parents in AUD Online Learning Assistance During the Covid-19 Pandemic 5(1), 91-98.

Nurpratiwiningsih, L., Yuliyanti, N., \& Kurniawan, PY (2021). Socialization of Parental Assistance to Children's Learning Process during the Covid 19 Pandemic Period. 1(02), 31-36.

Riati, IK (2016). EARLY CHILDHOOD CHARACTER. 4.

Sari, DK, \& Suprapti, A. (2018). No Title. 3(1), $1-6$. 